\title{
The meaning given by the healthcare professional to labor and humanizing delivery*
}

\author{
O significado dado pelo profissional de saúde para trabalbo de parto e parto bumanizado \\ El significado dado por el profesional de salud al trabajo de parto y parto bumanizado
}

\author{
Alessandra dos Santos Mabuchi ${ }^{1}$, Suzete Maria Fustinoni ${ }^{2}$
}

\begin{abstract}
Objective: To understand the meaning the healthcare professional in charge of the woman in childbirth gives to labor and humanizing delivery. Methods: This is a qualitative research with a phenomenological perspective. Seven physicians and four nurses working at the obstetric center of a public hospital in the city of São Paulo were interviewed. Results: After data analysis, two subthemes emerged: Understanding labor and humanizing delivery as a group of differentiated healthcare and behavioral measures, and Identifying failures in the search for healthcare humanization. Conclusion: The study showed that there are still disagreements regarding what is understood as humanizing delivery and what is done in practice. Humanization remains a government policy that is far from efficient, not only because of infrastructural deficits or financial shortages, but because of a lack of contact with the theme, resulting in healthcare that is not individualized or human.
\end{abstract}

Keywords: Humanizing delivery; Humanization of assistance; Professional practice; Obstetrical nursing

\section{RESUMO}

Objetivo: Compreender o significado que o profissional de saúde que atende a parturiente, dá para trabalho de parto e parto humanizado. Métodos: Trata-se de uma pesquisa qualitativa com perspectiva fenomenológica. Foram entrevistados sete médicos e quatro enfemeiras que atuavam no Centro Obstétrico de um hospital público do Município de São Paulo. Resultados: Após a análise dos dados emergiram dois subtemas: Compreendendo trabalho de parto e parto humanizado como um conjunto de medidas assistenciais e de comportamento diferenciado, e Identificando falhas na busca de humanização da assistência, os quais ao serem sintetizados deram origem ao fenômeno maior da experiência dos sujeitos: Vivenciando a desarmonia entre teoria e prática na busca pela humanização da assistência. Conclusão: O estudo evidenciou que ainda há discordância referente ao que se entende por parto humanizado e o que se realiza na prática. A humanização continua sendo uma política governamental longe de se tornar eficaz, não apenas pelos déficits na infra-estrutura ou escassez financeira, mas pela carência de contato com a temática, contribuindo para que a assistência, oferecida seja, muitas vezes, despersonalizada e desumana.

Descritores: Parto humanizado; Humanização da assistência; Prática profissional; Enfermagem obstétrica

\section{RESUMEN}

Objetivo: Comprender el significado que el profesional de salud que atiende a la parturienta, da al trabajo de parto y parto humanizado. Métodos: Se trata de uma investigación cualitativa con perspectiva fenomenológica. Fueron entrevistados siete médicos y cuatro enfermeras que trabajaban en el Centro Obstétrico de un hospital público del Municipio de Sao Paulo. Resultados: Después del análisis de los datos emergieron dos subtemas: Comprendiendo el trabajo de parto y parto humanizado como un conjunto de medidas asistenciales y de comportamiento diferenciado, e Identificando fallas en la búsqueda de la humanización de la asistencia, los cuales al ser sintetizados dieron origen al fenómeno mayor de la experiencia de los sujetos: Vivenciando la desarmonía entre teoría y práctica en la búsqueda de la humanización de la asistencia. Conclusión: En el estudio se evidenció que aun hay discordancia referente a lo que se entiende por parto humanizado y lo que se realiza en la práctica. La humanización continúa siendo una política gubernamental que está lejos de volverse eficaz, no sólo por los déficits en la infra-estructura o escasez financiera, sino también por la carencia de contacto con la temática, contribuyendo a que asistencia, ofrecida sea, muchas veces, despersonalizada y deshumana.

Descriptores: Parto humanizado; Humanización de la atención; Práctica profesional; Enfermería obstétrica

* Study developed in the Municipal Hospital Vereador José Storopolli (Hospital Vila Maria), São Paulo (SP), Brazil

1 Student in the Obstetric Nursing specialization course at the Universidade Federal de São Paulo - UNIFESP - São Paulo (SP), Brazil.

${ }^{2}$ MD, Associate Professor at the Universidade Federal de São Paulo - UNIFESP - São Paulo (SP), Brazil. 


\section{INTRODUCTION}

According to the dictionary, "humanizing comes from humantizing, which means 1 . To make something become human; To give human condition. 2. Act of humanizing. 3. To make something become benevolent. 4. Affable, treatable. 5. To make one acquire polite social habits; To civilize"(1).

By understanding humanization under the philosophical perspective, it can be translated as a free and inclusive ideal of the subjects' manifestation in the organization of social practices, especially healthcare, promoted by ever more symmetrical interactions that allow for mutual comprehension and construction of values and truths ${ }^{(2)}$.

The humanization of healthcare is of extreme importance to assure that a unique moment like childbirth can be experienced in a positive and rewarding way. Retrieving human contact, listening, welcoming, explaining and creating bonds are indispensable healthcare requisites. Privacy, autonomy and respect for the woman in labor are as important as physical care, performance of proven beneficial procedures and reduction of interventionist measures, defended in the Program for Humanization of Prenatal and Delivery Care (PHPN), instituted by the Ministry of Health in $2000^{(3)}$. However, reality remains far from theory.

Studies show that, even in institutions where the humanizing delivery model is followed, distortions persist about the humanization process, which makes healthcare less individualized and more mechanistic, where the woman, who should be the protagonist of the whole process, becomes submissive, afraid and confused. Differentiated healthcare measures proposed by the PHPN are introduced by the professionals without any significance for either party ${ }^{(4-5)}$.

The predominant healthcare model in Brazil is quite different from what exists in other countries. Still, when a woman in labor is admitted, she is usually taken away from her family members and submitted to doubtful processes of referral and results, despite all humanization policies defended by the government. There are primordial setbacks to be overcome, such as low salaries, difficult work conditions, excessive demand, insufficient conditions for adequate diagnosis and treatment, precarious infrastructure that does not meet the necessities put forward by the humanization guidelines, besides the fact that professionals do not have enough knowledge about humanization ${ }^{(6-7)}$.

A study performed at a university hospital seeking to adequate itself to the PHPN revealed enormous resistance from healthcare professionals, especially because other forms of healthcare were unknown to them, showing the need to adapt to the new model ${ }^{(8)}$.
This context made the author question the effectiveness of the humanizing model currently practiced in the country. The author believes that it is only by knowing and reinstating the proper value of "healthcare humanization" that it will be possible to improve deficiencies, so that women and healthcare professionals can "develop relations that are less unequal and authoritarian"(8). Besides, it will assure the utilization of evidence-based routines that can guarantee harmonious teamwork and more adequate, uniform care, which can meet the precepts of the healthcare policy and retrieve the women's autonomy and decision power.

Therefore, the present study aimed to understand the meaning the healthcare professional delivering care to women in labor confers to labor and humanizing delivery. The assumption was that this study would allow for the development of the theme in its multiple dimensions, enabling reflections on the healthcare provided to the women during the pregnancy-puerperal cycle, focusing on the woman in labor in this research, and the true sense of holistic and humane care delivery, in a directed, intentional and conscious way, optimizing the healthcare offered.

\section{METHODS}

This is a qualitative research from a phenomenological perspective, which permits showing, describing and understanding the reasons present in the phenomena expressed in the empathic interview, enabling the achievement of the proposed objective through the analysis of the perceptions within an immediate reality, seeking the meaning and assumptions of the phenomena ${ }^{(9-10)}$.

In order to study the data coming from the subjects' experiences, the steps determined by the phenomenological model proposed by Amadeo Giorgi were chosen, since this method provides a transparent work system that allows for a conclusive demonstration of the interpretation of the data through the subject's conscience $^{(11)}$ :

1. Global view: Reading the data to capture their meaning in the face of the object of study.

2. Division of the report in meaningful units: Having a view of the whole, specific points are highlighted, focused on the object of research.

3. Transcription of each unit of meaning in psychological language: By outlining the units of meaning, the psychological comprehension about them is expressed.

4. Specific synthesis: A synthesis of the units of meaning is built, which will originate the general synthesis and the comprehension of the investigated phenomenon, with the emergence of categories that will consist in the results of the research. 
Data collection was executed at a public hospital in the city of São Paulo, in October and November/2007, through non-directive, open-ended interviews, recorded with healthcare professionals who worked as mediators of the parturition process at the Obstetric Center of the institution. Data collection ended after the eleventh interviewee, when data saturation occurred. Seven physicians and four nurses participated in this study.

The guiding question of the study was: What do labor and humanizing delivery mean to you?

The research was approved by the Review Boards of the hospital where the data were collected and of the Federal University of São Paulo.

Regarding the ethical principles of research involving human beings, in accordance with Resolution 196/96 of the National Health Council, the participants were asked to volunteer for the research by signing the term of consent.

Pseudonyms were used to preserve the respondents' anonymity.

\section{RESULTS}

The obtained data allowed for the development of the central phenomenon Experiencing disharmony between theory and practice in seeking the humanization of healthcare in labor and childbirth (Figure 1), which represents the ambiguity between concept / comprehension of the healthcare professionals for labor and humanizing delivery and their daily practice in the parturition process. The subjects visualized humanizing delivery as a compound of measures, not only healthcare, but also behavioral measures, which distinguishes healthcare from traditional methods, with benefits for the woman, the future newborn and the family. On the other hand, despite the focus on retrieving natural childbirth, visualizing the woman as the protagonist of the process, some professionals understood humanizing delivery as a deeply flawed governmental policy, with dichotomies between theory and practice, between the actions of several healthcare professionals, and mainly, lack of teaching-learning about the theme.

"In theory, the bumanizing delivery is one where the woman should be put as the protagonist of the parturition process (...). In Brazil, unfortunately, the meaning of humanization is much more focused on governmental policies. The parturient ends up being the least favored (...).” (SEALIAH)

The central phenomenon also involves the integration between the categories found in phenomena 1 and 2, "understanding labor and humanizing delivery as a group of differentiated healthcare and behavioral measures", and "identifying flaws in the search for healthcare humanization", indicating that patients, family members and interviewed the healthcare professionals were continuously moving between two extremes, where the disagreement between what was understood and what was performed by healthcare humanization happened daily.

\section{Understanding labor and humanizing delivery as a group of differentiated healthcare and behavioral measures}

The professionals understood "Understanding labor and humanizing delivery as a group of differentiated healthcare and behavioral measures" as the search for the well-being of the woman during the parturition process, having her as the protagonist of the situation, respecting her wishes and preferences as goals to be attained. This definition composed categories that describe how these professionals seek to offer humanized healthcare to the parturients.

Viewing the parturient as the protagonist of the parturition process in a welcoming environment was the key element, the trigger of the concept the healthcare professionals expressed. The subjects defined the humanization of labor and childbirth healthcare according to the guidelines defended by the Ministry of Health. They visualized the importance of welcoming, of respecting the woman's desires and decisions, addressed the importance of decreasing interventionist practices and understood the presence of a partner as a right and a positive aspect for the woman.

"(...) bumanizing delivery is that where the woman, the desires of the woman are respected (...) it is making her have as much comfort as possible (...)." (HARAEL)

When visualizing the parturient as unique, with rights to be respected, the healthcare professionals perceived dialogue as a differential in humanizing healthcare, which, according to them, should be considered as early as in prenatal care, seeking to answer the questions of these women, with orientations and clarification of doubts and fears regarding pregnancy, labor, childbirth and puerperium.

"For me, humanizing delivery is (...) explaining to the patient what is happening (...) the patient has to know how labor works, what is normal and what is not in labor (...)." (MEBAHIAH)

The interviewed professionals showed interest in the measures defended by the Ministry of Health as "humanizing", understanding relaxation techniques as actions of comfort. However, it was verified that these techniques were not habitually used.

"I believe that the ball, the bath help delivery occur faster, so 
that it does not take too long, for the woman to feel less pain (...) but usually, when there are no students here, we almost never offer it.” (MEHIEL)

The presence of the companion as beneficial in the process of labor/childbirth was viewed as a differential in the humanizing delivery model, allowing the woman to visualize parturition in a safer, more protected way and, consequently, to experience a less painful sensation.

“(...) the presence of the accompanying partner is something very important, because it conveys a feeling of safety, eliminating tension and fear (...).” (NITH-HAIAH)

Another way of conceiving labor and humanizing delivery was exposed, when the professionals were shown to avoid interventionist practices. Therefore, in the research institution, the parturient received a light meal, enemas were not performed and, when performed, amniotomy and episiotomy were careful and not routine processes. Still, sometimes, invasive and doubtful processes were employed by some professionals.

"For me, bumanizing labor is to try and provide healthcare that is the least medicalized possible, using oxytocyn when necessary (...) Nowadays, we let the patients eat during labor, this is humanizing (...) performing trichotomy in all of them, nowadays we don't do it anymore (...)." (MEBAHIAH)

Visualizing cesarean delivery as humanizing, considered

EXPERIENCING THE DISHARMONY BETWEEN THEORY AND PRACTICE WHILE SEEKING THE HUMANIZATION OF LABOR AND CHILDBIRTH HEALTHCARE

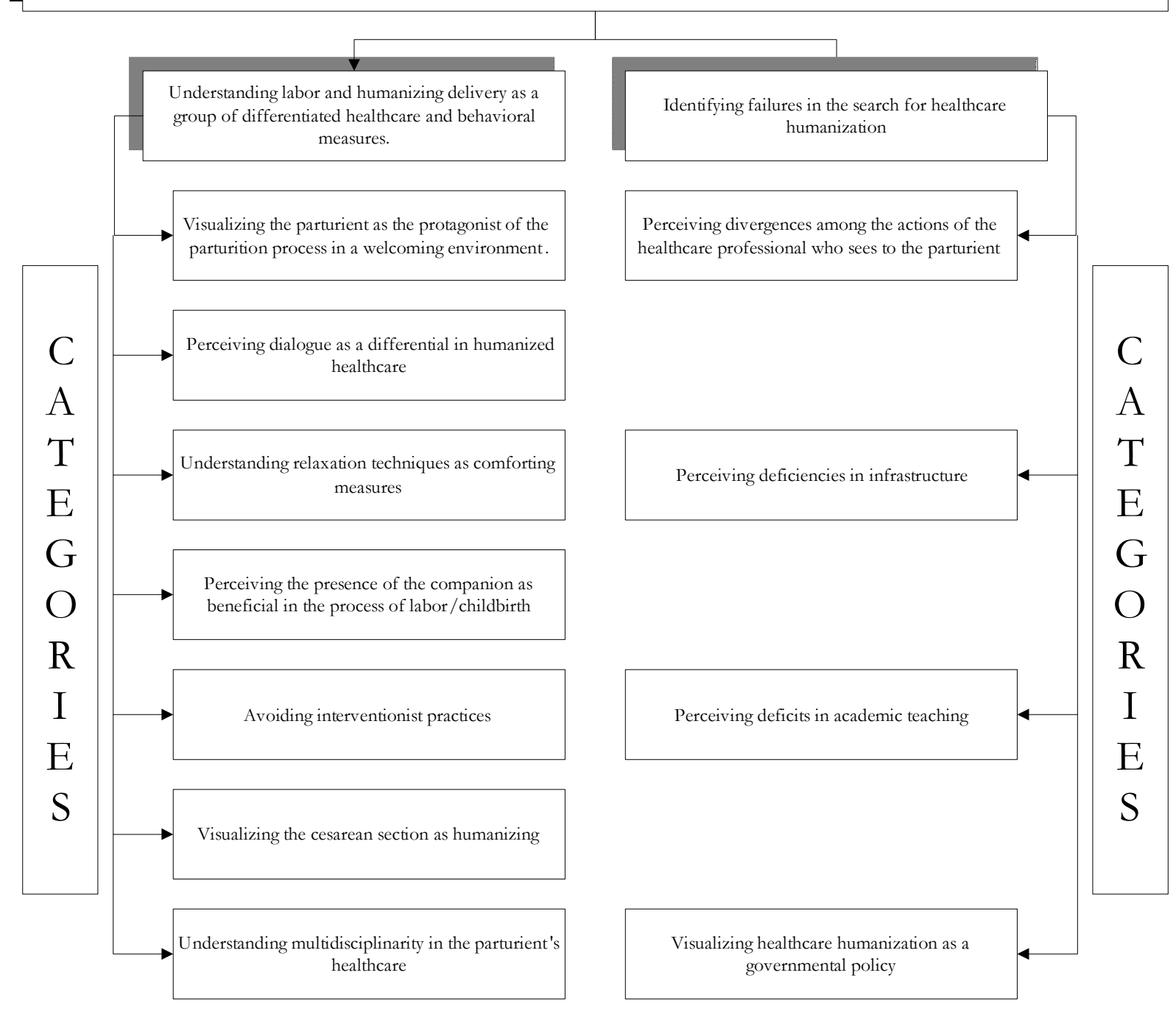

Figure 1 - central phenomenon - Experiencing disharmony between theory and practice in the search for humanization of labor and delivery healthcare. 
as such by the interviewees, it aims to minimize aggravations to the mother and the fetus when wellindicated.

"Depending on the case, the cesarean section is also part of bumanization, isn't it? I think that, if it gets to a point where there is no more hope for normal delivery, the cesarean is also a relief for the patient." (ELEMIAH)

"Understanding multidisciplinary aspects in care for the parturient" was an enormously important category, since multidisciplinary care was seen as fundamentally relevant to care for the parturient, since she needs certain physical, social, spiritual, psychological and biological aspects to be addressed.

"(...) I think that, the more people from the area, the obstetrician, the nursing personnel, people who know, who participate, I think the patient feels more at ease (...)." (MENADEL)

Identifying flaws in the search for healthcare humanization

When defining labor and humanizing delivery, the professionals identified flaws in the search for healthcare humanization, which involved the autonomy of the professionals, their availability, their knowledge, their involvement with the multiprofessional team and, also, physical and infrastructural limitations.

In this context, physicians and nurses noticed divergences among the actions of the healthcare professional seeing to the parturient, because each professional conducted the shift according to his/her own judgment. The multiprofessional team, which should work as a group, seeking to provide integrated healthcare with bilateral benefits, was sometimes found dispersive, incoherent and egocentric.

"(...) the medical staff is like that, very resistant (...) I think that two or three are in favor, the rest, it's always a struggle for us to get the pregnant woman to enter with her partner (...) and then, since there aren't obstetric nurses there, they don't have this view, it's even more difficult. You can do it in one shift, and in the other you can't." (MANAKEL)

The professionals also noticed deficiencies in infrastructure, such as the inexistence of screens, of waiting rooms for companions, cramped physical space, few beds and uncomfortable chairs. Medication, materials and basic utensils (such as disposable cups) were lacking. Besides, there were few motivational or improvement courses for the professionals. Altogether, a series of limitations that made it difficult to offer effective, individualized and adequate healthcare was detected, acting as obstacles in the implantation process of healthcare humanization measures.

"About the permanence of a partner, this is a bit difficult, even because of the physical space, the accommodations, it's small, there are no dividing walls (...).” (YESALEL)

The category "perceiving deficits in academic teaching" showed the teaching-learning problem in our country. Only one of the respondents mentioned attending classes about healthcare humanization during the undergraduate course. The situation was shown to be even more problematic in Medicine courses: the students do not hear of the theme very often and, when they do, the topic is usually diluted into another.

"(...) nowadays, there is no humanization course at the medical school. There are comments during classes, but nothing specific. A class about this single topic would be important (...) comments alone are not enough." (HARAEL)

The result of all aspects exposed in this phenomenon peaked with the category visualizing the humanization of healthcare as a governmental policy because, even with all efforts by the Ministry of Health in the implementation of the PHPN, after 2000, the subjects continued experiencing divergences between what was predicted and what was done. This generalizes the healthcare that was supposed to be individualized, relegating it to following norms in order to receive awards and gratifications, disregarding the experience of the parturients.

"Although the Ministry of Health routines about healthcare bumanization are recommended, this is very beautiful on paper, reality is different. Women are admitted into hospitals and do not know what awaits them (...) Sometimes they're denied the right to have a partner by their side (...) Interventionist measures are adopted (...) The woman feels pain, pain and morepain, is this humanization? There is no respect for the woman there." (SEALIAH)

\section{DISCUSSION}

This study showed that the healthcare professional generally understands humanization in labor and childbirth as a benefit and a right of the woman, validating the principles defended by the Ministry of Health in this process.

In this scenario, other references note that the professional and the woman, during the parturition process, are in contact with this duality of feelings, practices and behaviors that question the effectiveness of the humanizing model. It is necessary for theoretical/practical learning to be offered in order to place childbirth in a respect-based context, with autonomy, individuality, 
power of decision and exchanges between the professional and the parturient $t^{(4,7,12-14)}$.

The Ministry of Health states that humanization would be to receive the woman, her family members and the newborn with dignity, having the professionals perform their duties with ethics and solidarity so as to create a welcoming environment and to institute hospital routines that break away from the traditional model ${ }^{(3)}$. In this study, the healthcare professionals conceived labor and humanizing delivery according to the guidelines established by the Ministry of Health, in which attempts should be made to transform the delivery scenario into an "environment similar to that of the parturient's home", visualizing the importance of the family members, of a welcoming, clean and comfortable environment, offering meals, measures for pain relief, restriction of invasive measures, among others.

The women expect to receive information and explanations about their labor and delivery. It is extremely important for them that the physician explains the procedures to be performed, talks about the fetus' wellbeing, talk to the parturient calmly and gently, so that she will feel safer, more confident and will collaborate ${ }^{(12)}$. In the research institution, the healthcare professionals sought to answer the questions of the patients, although most of them did it shortly and objectively. The fact that most explanations were provided by students (either from medical or nursing schools) accompanying the parturient is relevant, perhaps because they interacted with the woman more directly, since they were available to stay by their side longer.

The World Health Organization defends that the bath, the encouragement to take different positions, freedom of movement, techniques to relieve pain and presence of a companion are some of the practices to be encouraged in labor and childbirth. However, these techniques sometimes end up being applied inadequately, since the parturients do not know this form of healthcare and do not have the right to choose, making the situation inhuman ${ }^{(3-5)}$. Inadequate or little use of these techniques, besides difficulties to accept a companion during labor and childbirth, were also identified in this study. The professionals mention the importance of these techniques in general, except for the bath, which ends up being an "obligation" of the parturient when she is admitted at the pre-partum unit. However, the others were performed mostly when there were students at the institution accompanying the parturient, usually nursing students. If these were absent, the methods were rarely offered. As for the companion, their presence was reserved to short occasions, because some professionals considered this right inopportune.

When well-indicated, the cesarean section plays a fundamental role in modern obstetrics, because it works as a reducer of maternal and perinatal morbidity and mortality ${ }^{(15)}$. It was evident in this study that the healthcare professionals visualized the cesarean delivery, when recommended, as a humanizing delivery. However, it is fundamental to emphasize the need for the establishment of standards, systematization and implementation of educational actions for delivery - which covers the parturient, family and healthcare professional - so that the choice of a cesarean section does not overshadow normal delivery.

Multidisciplinary care is of fundamental relevance in order to assist the parturient, because she needs the physical, social, spiritual, psychological and biological aspects of healthcare to be addressed. Research shows, however, that there is still a lot of attrition between nurses and physicians in the parturient's healthcare ${ }^{(4,12,15)}$. The current study shows a deficiency related to the multiprofessional team. Some professionals worked together, aiming at a single objective and making healthcare more individual. Others, however, worked alone, disrespecting and limiting the autonomy of other team members.

Finally, the results emerging from this study also revealed to be possibilities of adjustment by pointing out limitations, divergences and difficulties found by the subjects, which made the healthcare they provided ambiguous. These limitations went far beyond financial or infrastructural deficits. They involved the professional's availability, the degree of autonomy, flexibility in accepting changes, development of skills like empathy, welcoming, attention, but, primordially, the lack of contact with the theme, which made healthcare not individual and inhuman. Several authors have written on this subject, concluding that humanization needs to equally cover healthcare professionals, because these also need humanized healthcare to balance the several limitations expressed in the work conditions, which neither support nor instigate them to provide humanized care ${ }^{(5-8)}$.

\section{FINAL CONSIDERATIONS}

The understanding attained at the end of this research is that, although a large share of the professionals have perfectly spoken about the benefits of a welcoming healthcare, where traditional practices can be replaced, it is still perceived that there is a long way ahead in the search for excellence in healthcare, where a holistic view of the human being is the goal.

Rigid hospital routines and a significant deficiency of human contact and dialogue still prevail in the parturient's healthcare. The woman has no autonomy and has little chance to express opinions about the evolution of her labor.

Labor and childbirth humanization are still a governmental policy which, although excellent in principle, 
is far from effective in most Brazilian institutions. This is due not only to visible deficits, but primordially to the lack of contact with the theme in all courses involving women's healthcare during the pregnancy-puerperal cycle, which makes healthcare not individualized and also inhuman.

It is necessary for health professionals to visualize the importance of the PHPN's differentiated care measures, so that these practices can really be offered to the parturients because of the benefits they aggregate, and not as a means to meet governmental norms or an attempt to "shut the woman up", at the peak of her contractions, pains and wincing, without any significance for all those involved.

It is necessary for humanism to start during prenatal care, or even earlier. Healthcare humanization is not initiated at the obstetric center and is not limited to the parturient. This care also needs to involve family members and

\section{REFERENCES}

1. Ferreira $\mathrm{ABH}$. Novo dicionário eletrônico Aurélio versão 5.0 em CD-ROM. São Paulo: Positivo Informática; 2004.

2. Ayres JRCM. Hermenêutica e humanização das práticas de saúde. Cienc Saude Coletiva. 2005; 10(3): 549-60.

3. Brasil. Ministério da Saúde. Programa de humanização no pré-natal e nascimento: informações para gestores e técnicos. Brasília: Ministério da Saúde; 2001.

4. Castro JC, Clapis MJ. Parto humanizado na percepção das enfermeiras obstétricas envolvidas com a assistência ao parto. Rev Latinoam Enferm. 2005; 13(6): 960-7.

5. Silva LM. Vivenciando a experiência da parturição em um modelo humanizado. [tese ]. São Paulo: Universidade Federal de São Paulo. Escola Paulista de Medicina. Curso de Enfermagem; 2005.

6. Wagner M. Pursuing the birth machine: the search for appropriate perinatal technology. London and Sydney: ACE Graphics; 1994.

7. Dias MAB. Humanização da assistência ao parto: conceitos, lógicas e práticas no cotidiano de uma maternidade pública [tese ]. Rio de Janeiro: Instituto Fernandes Figueira FIOCRUZ; 2006.

8. Griboski RA, Guilhem D. Mulheres e profissionais de saúde: healthcare professionals, because these also need humanizing care that encourages them to provide humanizing healthcare to the population.

In the end, the author believes that the key point for the success of humanization is based on "behavioral changes", where the visualization of "being a person", in its broadest sense, is the premise of healthcare. In this sense, making the healthcare professional aware of this theme is essential to balance divergences between theory and practice, optimizing the healthcare provided, which justifies the importance of the study for science and nursing.

Therefore, humanizing childbirth is to grant women their right: safe and welcoming healthcare that respects their physical, social, spiritual, psychological and biological necessities, regardless of the professional taking care of them or the institution where they are. This reality is still a challenge for all of us.

o imaginário cultural na humanização ao parto e nascimento. Texto \& Contexto Enferm. 2006; 15(1): 107-14.

9. Carvalho AS. Metodologia da entrevista: uma abordagem fenomenológica. Rio de Janeiro: Agir; 1997.

10 Matheus MCC, Fustinoni SM. Pesquisa qualitativa em enfermagem. São Paulo: Livraria Médica Paulista; 2006.

11 Giorgi A, editor. Phenomenology and psychological research. Pittsburgh, Pa.; Atlantic Highlands, N.J.: Duquesne University Press: Distributed by Humanities Press; c1985.

12 Fustinoni SM. As necessidades da parturiente: uma perspectiva compreensiva da ação social [tese]. São Paulo: Escola de Enfermagem da Universidade de São Paulo; 2000.

13 Bessa LF. Ação educativa: uma perspectiva para a humanização do parto?[tese]. Ribeirão Preto: Escola de Enfermagem da Universidade de São Paulo; 2002.

14 Reis AE, Patrício ZM. Aplicação das ações preconizadas pelo Ministério da Saúde para o parto humanizado em um hospital de Santa Catarina. Cienc Saude Coletiva. 2005; 10(Supl): 221-30.

15 Brasil. Ministério da Saúde. Secretaria de Políticas de Saúde. Área Técnica de Saúde da Mulher. Parto, aborto e puerpério: assistência humanizada à mulher. Brasilia: Ministério da Saúde; 2001. 